\title{
An Australian story: Paramedic education and practice in transition
}

\author{
Kylie O’Brien PhD ${ }^{1}$, Amber Moore BChinMed(Hons) $)^{1,2}$, David Dawson MBA ${ }^{3}$, Peter Hartley PhD ${ }^{3}$ \\ Affiliations: \\ ${ }^{1}$ Australian Institute of Applied Sciences, Melbourne, Australia \\ 2 Department of Medicine, Monash University, Melbourne, Australia \\ ${ }^{3}$ Victoria University, Melbourne, Australia
}

\section{SUMMARY}

In Australia, western medicine and the majority of allied healthcare professions are regulated via statutory regulation. For most of these allied healthcare professions, education has moved into the higher education (HE) sector and universities. The profession of paramedics is undergoing a transition in terms of scope of practice, and in particular education, moving from a post-employment model characterised by on-the-job training, to a pre-employment model, essentially full time university-based Bachelor degree education, similar to the change that occurred in nursing in Australia many years ago. How to produce work-ready graduates in the healthcare professions is of concern for educators and professional associations. Research into work-readiness in several healthcare fields has yielded important information that may be utilised by paramedic and other allied healthcare educators to improve courses. This paper discusses issues of transition of $\mathrm{HE}$ healthcare graduates into the workforce that need to be considered by educators, with a particular focus on the profession of paramedics in Australia. It also summarises key findings of research into work-readiness in a range of healthcare professions.

\section{Keywords}

Education, paramedics, transition, work readiness

\section{INTRODUCTION}

In Australia, the majority of mainstream healthcare professions are regulated via statutory regulation. In contrast, some other forms of allied health such as paramedics, and most forms of complementary and alternative medicine (CAM), except Chinese medicine, are self-regulated via professional associations. Education of many healthcare disciplines has undergone change over the past 30-40 years, with a move predominantly into universities within Australia. Until a few decades ago, for several mainstream healthcare disciplines, training was originally hospital-based, industry-based or in privately operated institutions. For example, nursing education began to transfer from hospital-based training into universities in the late 1970s and 1980s, with bachelor degrees finally being offered in the 1990s, though there were attempts to introduce nursing training into Australian universities as early as the 1930s. Chiropractic training moved into universities in
Australia in 1980, resulting in the demise of most of the 13 chiropractic colleges in existence (1). Osteopathy training moved into the HE sector in 1986 at Phillip Institute (later to merge with the Royal Melbourne Institute of Technology which achieved university status in 1994) with the first publically funded undergraduate course in Melbourne (2). Western medicine has been offered in Australian universities since the second half of the nineteenth century (3). Statutory regulation has preceded the move into the higher education system in many professions such as nursing and osteopathy, however, in the case of a newcomer to the national regulatory scheme, Chinese medicine, it has been the reverse of this process. The move of education into universities and $\mathrm{HE}$ sector contributes to the legitimation, maturing and as a consequence, 'mainstreaming' of a profession. 
With the transition of health profession education into the higher education (HE) system come several advantages, but also challenges. For example, how well do university courses train students in the practical skills needed in a profession? How well prepared are graduates to enter the health workforce? What is 'work readiness' fundamentally anyway? These are matters of concern for educators and the professions more broadly. The issue of transition of graduates into their first year of work has received some attention in several healthcare professions, in particular medicine, nursing and more recently, Chinese medicine (4-9). This paper will discuss the issues of transition of $\mathrm{HE}$ healthcare graduates into the workforce that need to be considered by educators, with a focus on changes occurring in one profession yet to become regulated via statutory regulation in Australia: paramedics. This profession is of particular interest as paramedic education is currently undergoing a similar transition that has previously been experienced by nursing: transitioning from a post-employment model (onthe-job training) to a pre-employment model whereby education is conducted in universities as bachelor degree programs. Attention will be given to research findings relating to transition into the workforce for several healthcare disciplines and conclude with some recommendations for educators. As background, the Australian practitioner regulatory context of healthcare professions and the relationship to education will be given.

\section{The Healthcare Practitioner Regulatory Context and its Relationship to Education}

\section{In 2009, the Health Practitioner Regulation}

National Law Act 2009 was passed, bringing all professions previously regulated under state and territory legislation under the one National Registration and Accreditation Scheme, and adding a few newcomers such as Chinese medicine. Each profession has their own board, and the Australian Health Practitioners Regulation Agency (AHRPA) is the coordinating body (http://www.ahpra.gov.au/). Health practitioner boards have the power to approve courses of study that lead to registration of graduates, typically setting out detailed guidelines for courses that need to be adhered to. A potential consequence of this is the homogenisation of courses as courses strive to ensure they meet Board course approval guidelines, and of course, increased costs associated with the approval process.

An advantage of delivery of healthcare courses by universities, and of statutory regulation and course approval by a (statutory) health practitioner Board, is their contributions to the legitimation of a profession. In the case of Chinese medicine, the move of education into universities, for example, provided a platform from which the profession was able to argue the case for statutory regulation (initially at the state level in Victoria). Achievement of this then contributed to its further legitimation, and eventually its inclusion in the National Registration and Accreditation Scheme. Its position within universities has also enabled greater opportunities for scientific research into Chinese medicine, again contributing to its legitimation.

Paramedics are unusual in being one of the mainstream professions not regulated under the national scheme, instead being self-accredited. Paramedics have gained authority to act (as a paramedic) by being employed by an ambulance service. In turn, the ambulance service is established by an Act of Parliament (see the Ambulance Services Act [Victoria] 1986 (10) and the Ambulance Services (Amendment) Bill 1998 (11). It is not inconceivable that in the future paramedics may be considered for inclusion under the national regulatory scheme. As such, the experiences of other healthcare professions in moving into HE institutions and becoming regulated via statutory regulation may be relevant to this profession.

\section{Paramedic Practice: Changing Scope and Education}

There has been a significant shift in the scope of practice of paramedics in Australia, from little more than a transporter of persons to hospital, to provision of emergency and non-emergency out of hospital and pre-hospital care and transport of sick and/or injured persons (12). Services include inter-hospital transport, specialised rescue services, responding to multi-casualty occurrences and capacity-building for emergencies (13). Paramedics now provide advanced and invasive medical techniques such as rapid sequence intubation and pre-hospital thrombolysis $(13,14)$. Many rural and remote areas have difficulty attracting and retaining healthcare professionals, and so paramedics often take on healthcare services normally carried out by other health disciplines in these remote locations. The Australian Council of Ambulance Authorities (CAA) reports that several ambulance services are exploring the expansion of the role of paramedics into primary healthcare provision and strengthening community healthcare collaborations in rural and remote areas (12).

Paramedic education has by necessity changed. Originally educational requirements were minimal 
(eg. only needing first aid training), then as the role of the paramedic began to extend, the next phase was (exclusively) in-house training (the 'post-employment' model) provided by state and territory-based ambulance service providers. In the current post-employment model, students are employed as student paramedics, complete on the job training with block release for classes (undertaken in the vocational education (VE) sector), then graduate with the paramedic qualification (usually at diploma level) with continuing employment ${ }^{14}$. More recently, there has been a transition towards a pre-employment model of training; university bachelor degree courses (15), as has occurred in other healthcare professions previously. Students complete a three-year bachelor degree program, apply for an advertised graduate paramedic job and complete an internship of 1-2 years (16).

The CAA heavily influences paramedic education, having established an accreditation process for tertiary entry-level paramedic programs to ensure that graduates from these programs have achieved the requisite competencies required for employment with an Australasian ambulance service as an entry-level ambulance paramedic (17). The CAA itself is comprised of employers (employing agencies) that accredit paramedic $\mathrm{HE}$ courses with industry and education representation on these accrediting panels, though the authority to practice is still governed by the individual employing services. Paramedic service provision is state and territory-based in Australia, with the six states and two territories each having a single service response. 'Ambulance Victoria', the state-based ambulance authority and major employer of paramedics in Victoria, requires that paramedics have a minimum of bachelor degree training in paramedics. Thus education in Victoria is bachelor degree level training within (five) universities. South Australia and Western Australia have discontinued all 'in-house' paramedic programs and moved to HE courses (12), whilst the other four states and territories still have a mixture of post-employment and preemployment training models. The trend suggests that the pre-employment model (i.e. tertiary education training) will become the sole entry point into the paramedic profession in the not-toodistant future (14). A total of twelve universities in Australia offer paramedic programs at bachelor degree level.

The paramedic profession is self-regulated, as previously mentioned. As has occurred in other professions in Australia, there is more than one professional association representing paramedic professionals. The two key industry bodies in this respect are the CAA and the Paramedics Australasia. They have both produced national competency standards for paramedics. Only the CAA currently provides accreditation of entry-level HE education courses, a process it began relatively recently. At a 2004 paramedic education symposium, it was clear that the industry supported a process of evaluation of paramedic education programs to ensure appropriate standards were achieved and there was consistency across programs in terms of course content and training outcomes. The CAA 'Guidelines for the Assessment and Accreditation of Entry Level Paramedic Education Programs' were developed and trialled out in several education providers in 2007 resulting in several $\mathrm{HE}$ courses gaining provisional accreditation. The guidelines were subsequently refined following this process ${ }^{16}$. It is also only relatively recently that the CAA published national competency standards ('Paramedic Professional Competency Standards') (18). This new external course approval process has therefore added a further layer of quality assurance (QA) reporting on top of internal institutional QA processes to education providers, but an advantage is that this process provides important benchmarking for individual institutions.

For the profession more broadly a national course approval/accreditation process can be seen as further evidence of the increasing legitimation of this profession. It is worth noting that the CAA's paramedic course accreditation guidelines are comprehensive, but in the opinion of the authors are not overly prescriptive in comparison to some course approval guidelines in healthcare professions that are regulated via statutory regulation. As stated in their guidelines, 'Accreditation is not about standardisation of paramedic education programs. Rather both the industry and the profession believe that variation in education programs is important and that education programs must be responsive to the needs to the industry, the profession and communities, including type of practice and workforce needs' (16). However, as previously mentioned, there are two different sets of national competencies developed by two separate authorities, the CAA and Paramedics Australasia. If Paramedics Australasia also begin the process of accrediting courses, this may lead to confusion within the paramedic education ranks. However, this is not unlike what has occurred in other professions such as Chinese medicine where there are two major professional associations representing Chinese medicine practitioners in Australia, each with their own course approval processes (allowing graduates from approved courses to be eligible for membership of these associations). Historically, Chinese medicine education providers have either applied to one or both associations for course approval. 
Whilst there has been significant movement with respect to undergraduate training, some states and territories have developed postgraduate programs to ensure paramedics have the skills needed to provide the healthcare services necessary for particular communities. For example, James Cook University in collaboration with the Queensland Ambulance Service and Queensland Health developed the first Graduate Certificate in Rural and Remote Paramedic Practice for Paramedics (12). This program provides paramedics with advanced clinical skills to be able to provide integrated health services in conjunction with other health professionals and therefore enable extended access to health service delivery in rural and remote areas of Australia. The Ambulance Service of New South Wales piloted an Extended Care Paramedic program that skills paramedics in the assessment and identification, planning and initiating of alternative non-emergency department care. In addition to their regular roles, Extended Care Paramedics provide low acuity patients with referral advice to alternative healthcare services where appropriate, rather than transporting them to the emergency department when this is not necessary (12). Health Workforce Australia (HWA) has recently announced a major project investigating the extending role of paramedics aimed at reducing emergency department (ED) presentations.

\section{Graduating Work Ready Healthcare Professionals}

Higher education providers in Australia are increasingly questioning educational training needs of graduates and how to best prepare graduates for the healthcare workforce. Graduates need to be skilled not only to work in the Australian healthcare context, but also internationally. 'Internationalisation of the curricula', for example, refers to internationalisation of the content of courses and the learning and teaching approaches/strategies (19). With the increasing professionalization of healthcare providers, more research is being undertaken in this area of education and the transition to practice.

The transition from final year of training into the workforce is a critical time. In the United States (US), 'approximately 50 to 80 percent of new college graduates leave their first job within the first three years' (20). There are several possible reasons including the difference in corporate culture compared with college culture, cognitive development, 'successful' and 'emotional' intelligence and competencies, workplace preparedness, psychosocial development, learning issues, motivational issues, interpersonal and group skills, career planning and skills for independent living (20). The issue of preparedness to enter the workforce has been investigated in several healthcare disciplines in Australia including medicine $(6,7)$, dentistry $(21)$, nursing (8), Chinese medicine (9), physiotherapy (22), occupational therapy (23) and paramedics. Table 1 sets out the key findings of these Australian studies. A number of issues are present in the investigation of health care graduates' work-readiness and the transition to practice. Students' expectations may affect their initial encounters with the workplace $(24,25)$, and their self-assessment of preparedness, clinical competence, and confidence may change over time (23). The increasing complexity of healthcare practice and differences between objectives of key stakeholders such as managers, funders, regulators, educators and patients, can force significant competing demands on new practitioners, which can be stressful (26). The expectations of employers and professional bodies may not yet be commensurate with those of regulators and educational institutions $(27,28)$.

Findings that students experience a significant change in learning environments when they enter the workplace support the growing focus on the development and provision of education that more closely reflects the clinical setting $(29,30)$.

Research in various healthcare fields has clearly demonstrated the value of clinical practical experience in preparing students for entering the workforce $(26,31-35)$. The importance of clinical training experiences to perceptions of preparedness for practice is a common theme in the Australian studies in Table 1.

Variety of clinical experiences is also important. For example, research in medicine has demonstrated the value of a variety of clinical placements including in rural communities in preparing graduates for their internship experiences (31). Surveys of two cohorts of medical graduates on retrospective selfperceptions of readiness for clinical practice found that significant differences between cohorts could be explained by undergraduate curriculum design (26). They concluded that early, structured workbased experiential learning with patient contact central to the experience may promote a more effective transition into the workforce (26). The type of clinical learning environment may also influence the perceived development of competencies and preparedness for clinical practice (36). The implications of this research derived from more established fields for educators within developing healthcare professions may include consideration of greater embedding of the formal curriculum (including assessment) within the professional practice setting. This may be especially important for university educators of 
paramedics as the field transitions from the field to tertiary education institutions. This is also of relevance to paramedic professional associations as key features of a profession are argued to include the education of a body of theory that is linked to practice, and an accreditation process that is determined by the wider profession (37). Thus, in developing and conducting their course accreditation processes, professional associations must also pay attention to what educational research is discovering with respect to helping students become work ready graduates.

Kilminster and colleague's research into the transition of first year medical interns and specialist trainee doctors challenges the notions of what constitutes preparedness (38). Their research suggests that performance of doctors is situational and relational, occurring in the interface between the individual and the work itself in a particular setting, and is not a set of skills or a personal attribute. They suggest that there are two problems with the notion of preparedness. The first is that preparedness depends on the notion of transfer of learning (from medical school and other settings) into a particular practice setting when there is no evidence in the literature that this occurs. Consequently, the theoretical underpinning should be that learning is situated and thus requires authentic practice within a community. The second problem they identify is that ideas about preparedness isolate individuals from the contexts, practices and social relationships within which they learn, when, they argue, their research demonstrates otherwise. Whilst they acknowledge that an individual's preexisting knowledge and skills are important, it represents only 'a part of what he or she needs in order to perform effectively as a new professional or in a new setting' (38), and that a doctor's performance is affected particularly by organisational practices, activity and culture. Their findings indicate that practice, performance and learning are inseparably interlinked and dependent on the specific setting, and they argue that doctors can't be fully prepared for transition. They also argue that any transition (such as working as a first year intern) should be recognised as a 'critically intensive learning period' and that the extent to which institutional learning cultures take this into account will contribute to how new doctors perform (38).

How individual healthcare professions tackle the issue of transition of graduates into the workforce is likely to vary. One recommendation repeated in the literature is for universities to work together with professional bodies, employers and students in order to develop effective learning environments and support the transition from student to working professional $(24,39,40)$. The development of professional praxis can be seen as a continuum from student to practitioner, as professional behaviours and identity begins during education and evolves over one's professional life $^{41}$. In Australia and overseas other formal transition support programs have been conducted in medicine $(42,43)$, nursing $(44-47)$, and occupational therapy $(48,49)$. These programs all report successful outcomes but vary in design and assessment. Programs such as The Royal Australasian College of Physicians' Physician Readiness for Expert Practice (PREP) program (details of which can be found at http://www.racp.edu.au/page/educational-andprofessional-development/prep-basic-training) are rigorous in terms of participation and assessment requirements, whereas programs such as the Occupational Therapy Australia's mentoring program are more flexible and less structured (http://www.mentorlinklounge.com/). In contrast, in the field of Chinese medicine (a recently regulated health profession) in which the majority of practitioners practice in private practice as solo practitioners, the main forms of support for graduates are membership of a professional association and development of informal mentoring relationships. Research into the perceptions of preparedness for clinical practice in final year Chinese medicine students (9) and a follow-up survey of recent graduates in Australia (40) identified a desire for formalised mentoring programs to assist transition into the workforce. The need to support students in the important transition phase in these and other fields of healthcare is being increasingly recognised.

\section{Challenges for Educators in the Field of Paramedics}

Returning once again to the field of paramedics, whilst there is general agreement within the industry that paramedic graduates need to be 'work-ready', there are differences in how this term is defined and therefore expectations of key stakeholders also differ. The CAA submission to the Australian Government's Department of Education, Science and Technology stated that: 'Paramedic higher education programs must produce work ready graduate paramedics with not only appropriate clinical ability but a multi skilled practitioner who is responsible for the out of hospital clinical care and safety of their patients and the community as a whole' (50). This definition of work-readiness is couched in terms of practical competence and discipline skills. This is not surprising, given that historically, the postemployment model was dominant and incorporated burst mode lectures in VE institutions where courses are inherently 'competency' based (that is, students are assessed with respect to competency to perform certain tasks or demonstrate particular skills). The CAA 
'Paramedic Professional Competency Standards V2.2 2013' (51) defines competency but does not address the concept of 'work readiness' explicitly. In contrast the concept of 'work readiness' from a $\mathrm{HE}$ perspective goes beyond discipline-specific competencies. In HE, courses aim to equip graduates with discipline-specific capabilities and generic capabilities (typically called 'graduate attributes' or 'graduate capabilities') such as the ability to think critically, communicate, problemsolve and be lifelong learners. Eley (31) also draws attention to the need to consider some of these 'soft skills' in relation to understanding what constitutes work readiness, in light of the demand in the paramedic profession for mentoring, as set out in the CAA's Paramedic Professional Competency Standards V2.2 2013 (Competency 9.3 'Participates in the mentoring, teaching and development of others') (51).

Higher education places great emphasis on developing graduates as critical thinkers, to question, challenge and research. There is therefore the potential for confusion when graduate paramedics enter a work environment that is steeped in the realm of 'competences', clinical practice guidelines and specific work instructions. Notwithstanding the problem of defining work readiness (whether this is in terms of competencies or in terms of discipline-specific learning outcomes and generic capabilities as described in HE courses), there is also the question of when this should be measured. Generic capabilities or graduate capabilities are a key component of benchmarking in $\mathrm{HE}$ and are typically considered at the end of an academic program, for example, via the 'Course Experience Questionnaire' which forms part of the Australian Graduate Survey, a national survey of graduates from Australian universities. It is common practice for health science programs such as paramedic programs to begin formal clinical practicum components of courses (that form the major clinical training within a course) once the student has completed a prescribed component of the course. Thus, it may be desirable to assess workreadiness at this point in time.

If work readiness is defined in terms of having the capabilities for a life-time working within a field that is likely to change significantly and potentially rapidly over the working life-time of the graduate, then how curricula can be best designed to achieve this is a fundamental issue for educators. As was the case in nursing, the post-employment model of paramedic training was very practically oriented by design and this could be seen as a strength of the model. The pre-employment model (university-based education), in contrast, provides less exposure to the clinical environment and thus clinical skills may be less well developed on graduation, though research by Dawson (15) (albeit confined to only one university) suggests that by the end of the internship year, supervisors found that graduates of bachelor courses were as skilled as trainees in the old post-employment program. The pre-employment model delivered in an $\mathrm{HE}$ institution has significant advantages by its underpinning pedagogical approach that nurtures the development of critical appraisal, research and problem-solving skills, and skills to be lifelong learners.

Mentoring is a feature of the CAA Professional Competency Standards V2.2 Standard 9.3 is the relevant item: '9.3 Participates in the mentoring, teaching and development of others'. In the postemployment model, students have substantial exposure to mentors ('preceptors') whereas in the pre-employment model, this opportunity only arises during clinical practicum and the postgraduate internship (31). Eley cautions that with a growing workforce, there is a growing demand for mentors and these roles are not always filled by senior paramedics, instead sometimes falling to recent graduates (31). Thus, educators need to pay attention to the development of mentoring capabilities in students as part of undergraduate programs. It cannot be assumed that they will simply develop these skills well once they are out in the field. Mentoring programs such as the 'PASS' (Peer Assisted Study Skills) mentoring program have been utilised in educational institutions such as Victoria University in Melbourne as a means of students assisting other students in particular units of study (typically those which are problematic). In this program, the student mentors are trained in mentoring. This has been piloted within the three year Bachelor of Health Science (Paramedics) with positive results. A recent study of final year paramedic students found that while they felt reasonably prepared to enter practice, respondents wanted more clinical placements and in a variety of areas within hospitals and the healthcare system (52). This may suggest that the work-readiness of paramedic students may not only be assisted within the university system but also through expanded engagement with industry.

In considering how best to design paramedic courses that will prepare graduates for an uncertain and changing future, it is prudent to take heed of what other professions have learned. For example, the research of Kilminster and colleagues (38) in medicine that indicates an interdependence between learning, practice and performance and the specific setting in which this occurs, and the notion of critically intensive learning periods, may be very relevant. Most HE paramedic bachelor degree courses are delivered over three years full time equivalent, after which graduates complete an internship with the relevant state ambulance authority (that is their 
employer). Given the increasing scope of practice of paramedics, particularly within rural and remote communities, it is suggested that a more effective four year bachelor program could be designed in collaboration with state ambulance authorities that combines the best features of the pre- and postemployment models. That is, a four year program could be developed that provides a strong pedagogical foundation with all that HE offers and sufficient hands-on practical experience under guided mentorship programs in a variety of community settings, including rural and remote communities. In this way, on graduation from the bachelor degree course, new paramedics are better prepared for the work they will undertake.

\section{CONCLUSION}

In Australia, increasingly education of the healthcare professions has entered the HE sector and universities, although there are some courses delivered in privately operated education institutions and in the vocational education sector. The paramedic profession, a mainstream healthcare profession that is not yet included in the national regulatory scheme, is undergoing a transition from a post-employment model to a preemployment model of education, three year degree courses delivered at universities. The move into the universities, along with external course accreditation via a professional association, are landmarks of a profession growing in maturity and legitimation. How to produce work ready graduates for the healthcare professions is a concern for all educators. Fortunately, there is an increasing body of knowledge about work readiness in healthcare professions, including recent research in the field of paramedics. When education of a profession is in a state of transition, such as is occurring in paramedics in Australia, there exist great opportunities to utilise the learning from other professions, collaborating with key stakeholders (the education institutions, the professional associations) and build the kind of courses that really will serve the needs of the Australian community.

\section{REFERENCES}

1. Baer, HA. The drive for legitimation by osteopathy and chiropractic in Australia: between heterodoxy and orthodoxy. Complementary Health Practice Review 2006; 11(2): 77.

2. Cameron, M. A comparison of osteopathic history, education, and practice in Australia and the United States of America. Australian Osteopathic Medicine Review 1998; 2(1): 612.
3. (RACGP) Royal Australian College of General Practitioners. Australian General Practice - A Celebration. Available at: http://www.racgp.org.au/history/celebration (accessed 4 March 2012).

4. Bojanic, K, Schears, GJ, Schroeder, DR, Jenkins, SM, Warner, DO, \& Sprung, J. Survey of self-assessed preparedness for clinical practice in one Croatian medical school. BMC Research Notes 2009; 2: 152.

5. Blumenthal, D, Gokhale, M, Campbell, EG, Weissman, JS. Preparedness for clinical practice: reports of graduating residents at academic health centres. JAMA 2001; 286(9): 1027-1034.

6. Dean, SJ, Barratt, AL, Hendry, GD, Lyon, PMA. Preparedness for hospital practice among graduates of a problem-based, graduate-entry medical program. Medical Journal of Australia 2003; 178(4): 163-166.

7. Hill J, Rolfe I, Pearson S, Heathcote A. Do junior doctors feel they are prepared for hospital practice? A study of graduates from traditional and non-traditional medical schools. Medical Education 1998; 32: 19-24.

8. Hart, AM, \& Macnee, CL. How well are nurse practitioners prepared for practice: Results of a 2004 questionnaire study. Journal of the American Academy of Nurse Practitioners 2007;19(1): 35-42.

9. Moore, A, O'Brien, K, Canaway, R. Chinese medicine students' preparedness for clinical practice: an Australian survey. Journal of Alternative \& Complementary Medicine 2010; 16(7): 733-743.

10. Ambulance Services Act (Victoria) 1986. Available at:

http://corrigan.austlii.edu.au/au/legis/vic/conso I_act/asa1986176/ [accessed 29 Oct 2013]

11. Ambulance Services Amendment Bill 1998. Available at: http://www.austlii.edu.au/au/legis/vic/bill/asb1 998266/ [accessed 29 Oct 2013]

12. (CAA) Council of Ambulance Authorities. Discussion Paper for the Review of the Report on Government Services. Council of Ambulance Authorities Inc. 2009. Available at: http://caa.net.au/images/stories/CAA submiss ion Review RoGS_July_2009.pdf [accessed 4 March 2012]

13. Willis E, Pointon T, O'Meara P, McCarthy C, Lazarsfeld Jensen A. Paramedic education: developing depth through networks and evidence-based research. ALTC Final Report 2009. Available at: http://www.acap.org.au/index.php

14. Edwards, D. Paramedic preceptor: work readiness in graduate paramedics. The Clinical Teacher 2011; 8: 79-82.

15. Dawson D. Evaluation of the Bachelor of Health Science (Paramedic) degree program 
at Victoria University. 2008. Masters Thesis, University of Melbourne.

16. (CAA) Council of Ambulance Authorities. (2010). Guidelines for the Assessment and Accreditation of Entry-level Paramedic Education Programs, Council of Ambulance Authorities Inc. Available at: http://www.caa.net.au/images/stories/PEPAP Guidelines Reviewed MAY 2010.pdf [accessed 20 February 2012]

17. Position Statement. Council of Ambulance Authorities. Available at: http://www.caa.net.au/index.php/education/ca a-position-statement

18. (CAA) Council of Ambulance Authorities. (2010). Paramedic Professional Competency Standards V.2 June 2010. Council of Ambulance Authorities Inc. Available at: http://www.caa.net.au/images/stories/ppcs.pdf [accessed 20 February 2012]

19. Arkoudis S, Yu X, Borland H, Chang S, Lang I, Lang J, Pearce A, Watty K. Finding Common Ground: Enhancing Interaction Between Domestic and International Students. 2010. Available at: http://www.cshe.unimelb.edu.au/research/proj ectsites/enhancing interact.html [accessed 10 Jan 2012]

20. Hettich, P. Transition processes from college to career. Paper presented at the Annual Conference of the American Psychological Association (108, August 4-8, 2000, Washington, DC). Available at: http://www.eric.ed.gov/ERICWebPortal/conten tdelivery/servlet/ERICServlet?accno=ED4473 68 [accessed 5 March 2012]

21. Arena G, Kruger E, Holley D, Millar S, Tennant M. Western Australian dental graduates' perception of preparedness to practice: a five year follow-up. Journal of Dental Education 2007; 71(9): 1217-1222.

22. Jones, M, Mclntyre, J, Naylor, S. Are physiotherapy students adequately prepared to successfully gain employment? Physiotherapy 2010; 96: 169-175.

23. Hodgetts, S, Hollis, V, Triska, A, Dennis, S, Madill, H, \& Taylor, E. Occupational therapy students' and graduates' satisfaction with professional education and preparedness for practice. Canadian Journal of Occupational Therapy 2007; 74(3): 148-160.

24. Waxman A, Williams B. Paramedic preemployment education and the concerns for our future: what are our expectations? Journal of Emergency Primary Health Care 2006; 4(4).

25. Sutton, G, Griffin, MA. Transition from student to practitioner: the role of expectations, values and personality. British Journal of Occupational Therapy 2000; 63(8): 380-388.

26. Brennan, N, Corrigan, O, Allard, J, Archer, J, Barnes, R, Bleakley, A, Collett, T, Regan de
Bere, S. The transition from medical student to junior doctor: today's experiences of tomorrow's doctors. Medical Education 2010;, 44: 449-458.

27. Murphy, GA, \& Calway, BA. Professional development for professionals: beyond sufficiency learning. Australian Journal of Adult Learning 2008; 48(3): 424-444.

28. Landrum, RE, Harrold, R, Schaeffer, G, Epting, K, Zinn, T Buskist, et al. Faculty Forum. Teaching of Psychology 2003; 30(2): 131-153.

29. Prince, KJAH, Van de Wiel, MWJ, Van der Vleuten, CPM, Boshuizen, HPA, Scherpbier, AJJA. Junior doctors' opinions about the transition from medical school to clinical practice: a change of environment. Education for Health 2004; 17(3): 323-331.

30. Cave, J, Woolf, K, Jones, A, Dacre, J. Easing the transition from student to doctor: how can medical schools help prepare their graduates for starting work? Medical Teacher 2009; 31: 403-408.

31. Eley, DS. Postgraduates' Perceptions of Preparedness for Work as a Doctor and Making Future Career Decisions: Support for Rural, Non-traditional Medical Schools. Education for Health 2010; 23(10): 1-13.

32. Doherty, G, Stagnitti, K, \& Schoo, AM. From student to therapist: Follow up of a first cohort of Bachelor of Occupational Therapy students. Australian Occupational Therapy Journal 2009; 56: 341-349.

33. Bleakley, A, \& Brennan, N. Does undergraduate curriculum design make a difference to readiness to practice as a junior doctor? Medical Teacher 2011; 33: 459-467.

34. Godefrooij, MB, Diemers, AD \& Scherpbier, AJ. Students perceptions about the transition to the clinical phase of a medical curriculum with preclinical patient contacts; a focus group study. BMC Medical Education 2010; 10: 28.

35. Robertson, LG, \& Griffiths, S. Graduates reflections on their preparedness for practice. British Journal of Occupational Therapy 2009; 72(3): 125-132.

36. Busari, JO, Verhagen, EAA, Muskiet, FD. The influence of the cultural climate of the training environment on physicians' self-perception of competence and preparedness for practice. BMC Medical Education 2008; 8: 51.

37. Greenwood, E. Attributes of a profession. Social Work 1957; 2(3): 45-55.

38. Kilminster S, Zuka M, Quinton N, Roberts T. Preparedness is not enough: understanding transitions as critically intensive learning periods. Medical Education 2011; 45: 10061015.

39. Kelly, C, Noonan, CL, Monagle, JP. Preparedness for internship: a survey of new interns in a large Victorian Health Service. Australian Health Review 2011; 35: 146-151. 
40. Moore, A, \& O’Brien, K. Confidence in clinical practice of Chinese medicine degree graduates one year after graduation: a pilot study. Journal Alternative \& Complementary Medicine 2012; 18(3): 1-11.

41. Tsang, A K L. Students as evolving professionals - student perceptions of the evolving professional (EP) concept as a professional socialisation approach. Conference paper submitted to the AARE Conference 2009 Canberra.

42. Fisher, JW, Thompson, BM, Garcia, AD. Integrative clinical experience: an innovative program to prepare for internship. Teaching \& Learning in Medicine 2007; 19(3): 302-307.

43. Frei, E, Stamm, M, Buddeberg-Fischer, B. Mentoring programs for medical students - a review of the PubMed literature 2000-2008. BMC Medical Education 2010; 10: 32.

44. Cleary, M, Matheson, S, Happell, B. Evaluation of a transition to practice programme for mental health nursing. Journal of Advanced Nursing 2009; 65(4): 844-850.

45. Almada, P, Carafoli, K, Flattery, JB, French, DA. \& McNamara, M. Improving the retention rate of newly graduated nurses. Journal Nurses Staff Development 2004; 20 (6): 268273.

46. Harrison, TM, Stewart, S. Clinical focus program: enhancing the transition of senior nursing students to independent practice. Journal Nursing Administration 2007; 37(6): 311-317.

47. Theobald, K, Mitchell, M. Mentoring: improving transition. Australian Journal of Advanced Nursing 2002; 20(1): 27-33.

48. Sangole, AP, Abreu, BC, Stein, F. Mentoring review and reflections. Occupational Therapy in Health Care 2006; 20(1): 1-16.

49. Wilding, C, Marais-Strydom, E, Teo, N. Mentorlink: empowering Occupational Therapists through mentoring. Australian Occupational Therapy Journal 2003; 50(4): 259-261.

50. (CAA) Council of Ambulance Authorities Inc. Submission to the Australian Government: Department of Education, Science, and Training. Review of the impact of the Higher Education Support Act 2003; Funding cluster mechanism (including funding of clinical disciplines). Pipeline arrangements for funding of a new Commonwealth supported places. Discussion paper 2006. Available at: http://www.dest.gov.au/NR/rdonlyres/2F51524 4-5225-4DFF-BE371898BF1F9C7D/15848/048TheCouncilofAmb ulanceAuthoritiesRevised.pdf [accessed 19 March 2012]

51. Council of Ambulance Authorities Professional Competency Standards Version 2.2 Paramedics. February 2013. Available at URL: http://www.caa.net.au/attachments/article/91/p aramedics_professional_competency standar ds V2.2 20 Feb 2013

52. O’Brien, K, Hartley, P, Dawson, D, \& Moore, A. Work readiness of final year paramedic students at Victoria University: a survey. Accepted for publication Australasian Journal of Paramedicine 2013.

53. Levett-Jones, T, Gersbach, J, Arthur, C, \& Roche, J. Implementing a clinical competency assessment model that promotes critical reflection and ensures nursing graduates' readiness for professional practice. Nurse Education in Practice 2011; 11: 64-69.

54. Walker, A, Yong, M, Pang, L, Fullarton, C, Costa, B, \& Dunning, A. Work readiness of graduate health care professionals. Nurse Education Today 2013; 33(2): 116-122.

55. McCall, L, Wray, N, \& Lord, B. Factors affecting the education of pre-employment paramedic students during the clinical practicum. Journal of Emergency Primary Health Care 2009; 7(4).

56. O'Meara, P, Tourle, V, Madigan, V, \& Lighton, D. Getting in touch with paramedic student career intentions. Health Education Journal 2011:1-10. 


\begin{tabular}{|c|c|c|}
\hline $\begin{array}{l}\text { Healthcare } \\
\text { profession }\end{array}$ & Reference & $\begin{array}{c}\text { Type of } \\
\text { study/outcome } \\
\text { variables }\end{array}$ \\
\hline Medicine & $\begin{array}{l}\text { Hill, Rolfe, } \\
\text { Pearson, } \\
\text { Heathcote, } \\
1998 \text { (7) }\end{array}$ & $\begin{array}{l}\text { Written survey of } \\
\text { perceptions of interns } \\
\text { working in New South } \\
\text { Wales preparedness for } \\
\text { hospital practice in eight } \\
\text { key areas. Compared } \\
\text { graduates of universities } \\
\text { using a more traditional } \\
\text { program model with } \\
\text { graduates of problem- } \\
\text { based curricula } \\
\text { programs. }\end{array}$ \\
\hline
\end{tabular}

Medicine Dean, Barratt, Graduates of the first Hendry, \& Lyon, 2003 (6) intake of University of Sydney graduate-entry medical program were asked about their preparedness for hospital practice using questionnaires and semi-structured interviews; results were compared with other programs.

$\begin{array}{ll}\text { Medicine } \quad \text { Eley } 2010 \text { (31) } & \text { Junior doctors' } \\ & \text { perceptions of level of } \\ & \text { preparedness for } \\ & \text { hospital work; semi- } \\ & \text { structured interviews } \\ & \text { with postgraduate year } \\ & \text { one and two junior } \\ & \text { doctors in Queensland, } \\ & \text { Australia. }\end{array}$

Medicine Kelly, Noonan, New interns surveyed at \& Mongale, a large Victorian 2011 (39) metropolitan health service on self-reported confidence and preparedness for common intern tasks.
Interns perceived that their

undergraduate medical training from both traditional and non-traditional medical schools adequately prepared them for hospital practice in the areas of patient management and understanding of science, however problem-based curricula program graduates rated their undergraduate preparedness as higher in the areas of interpersonal skills, confidence, collaboration with other health care workers, preventative care, holistic care and self-directed learning.

Graduate-entry, problem-based program graduates were found to be at least as well prepared for hospital practice as graduates from traditional and undergraduate problem-based programs.

Respondents that underwent training in smaller, non-traditional medical schools felt better prepared at internship. Factors that contributed to building confidence identified were: more handson experience as students, more patient contact, better grounding in basic sciences. Junior doctors identified a lack of career guidance to help them transition from student to doctor.

Most felt reasonably prepared by their university training for most but not all intern tasks. Domains of work-readiness that could be improved included the preoperative patient review, handover, fluid and medication management, patient admissions, assessment of unstable patients, communication with patients and families, and pain management. 
Dentistry

Arena, Kruger, School of Dentistry in Holley, Millar, Western Australia aimed \& Tennant, to identify the strengths 2007 (21)

Nursing

Hart \&

Macnee, 2007

(8) and weaknesses of the curriculum as perceived by graduates and to compare the perceptions of those graduates who completed a focused clinical experiential program (CEP) to those who did not. Survey mailed to graduates, with questions based on the graduate outcomes of the dental school.

Cross-sectional written survey in which nurse practitioners (NP) were asked to rate their level of preparedness when they completed their educational program; distributed to NP's at two national conferences.

\begin{tabular}{|c|c|c|}
\hline Nursing & $\begin{array}{l}\text { Cleary, } \\
\text { Matheson, \& } \\
\text { Happell, } 2009 \\
(44)\end{array}$ & $\begin{array}{l}\text { Questionnaire based } \\
\text { study of participants in a } \\
12 \text { month Australian } \\
\text { transition to practice } \\
\text { program in Mental } \\
\text { Health Nursing; } \\
\text { assessed perceived } \\
\text { satisfaction and impact } \\
\text { on knowledge and } \\
\text { confidence. }\end{array}$ \\
\hline Nursing & $\begin{array}{l}\text { Levett-Jones, } \\
\text { Gersbach, } \\
\text { Arthur \& } \\
\text { Roche, } 2011 \\
\text { (53) }\end{array}$ & $\begin{array}{l}\text { Assessed clinical } \\
\text { competence of third } \\
\text { year nursing students in } \\
\text { Newcastle, Australia. }\end{array}$ \\
\hline $\begin{array}{l}\text { Medicine \& } \\
\text { Nursing }\end{array}$ & $\begin{array}{l}\text { Walker, Yong, } \\
\text { Pang, } \\
\text { Fullarton, } \\
\text { Costa, \& } \\
\text { Dunning, } 2013 \\
\text { (54) }\end{array}$ & $\begin{array}{l}\text { Investigated work } \\
\text { readiness via qualitative } \\
\text { interviews with medicine } \\
\text { graduates, nursing } \\
\text { graduates and } \\
\text { organisational } \\
\text { representatives at a } \\
\text { regional hospital in } \\
\text { Australia. }\end{array}$ \\
\hline
\end{tabular}

Most graduates, whether completing the CEP or not, perceived themselves to be prepared, competent, and confident to practice as dentists. Respondents reported feeling most confident in managing problems that they most frequently encountered during training.

Results indicate that formal NP education is not preparing new NPs to feel ready for practice. Fifty one percent perceived that they were only somewhat or minimally prepared after completing their basic NP education. Current age, years since graduation from an NP program, and age when attending the NP program did not differ significantly for those who felt prepared versus those who did not.

Participants expressed a high level of satisfaction with the transition to practice program. It was perceived to provide enhancement of knowledge and confidence for graduate nurses entering the profession, and experienced nurses transitioning from one clinical setting to another.

Findings support the premise that quality clinical assessment requires nursing students' exposure to complex challenges undertaken in authentic clinical contexts, observed by registered nurses who are trained as assessors and have a strong educational and clinical background.

Four factors were found to be important to work readiness: social intelligence, organisational acumen, work competence and personal characteristics. While organisational representatives reported social intelligence and clinical skills as critical to graduate competency, graduates perceived themselves as unprepared in these areas. 


\begin{tabular}{|c|c|c|}
\hline $\begin{array}{l}\text { Chinese } \\
\text { Medicine }\end{array}$ & $\begin{array}{l}\text { Moore, } \\
\text { O'Brien, \& } \\
\text { Canaway, } \\
2010 \text { (9) }\end{array}$ & $\begin{array}{l}\text { Investigation into } \\
\text { perceptions of } \\
\text { preparedness for clinical } \\
\text { practice of final year } \\
\text { CM students in } \\
\text { Australia. Written survey } \\
\text { with Likert scale } \\
\text { questions and open- } \\
\text { ended responses } \\
\text { focusing on eight } \\
\text { dimensions relating to } \\
\text { practice: } \\
\text { Interpersonal Skills, } \\
\text { Confidence/Coping } \\
\text { Skills, Professional } \\
\text { Networks, } \\
\text { Professional } \\
\text { Practice } \\
\text { Management, } \\
\text { Professional Patient } \\
\text { Management, } \\
\text { Prevention, Holistic } \\
\text { Care, and Self- } \\
\text { Directed Learning. }\end{array}$ \\
\hline
\end{tabular}

Chinese

Moore \&

medicine

O’Brien, 2012

(40)

Occupational
Therapy

Dogherty, Stagnitti, \& Schoo, 2009

Paramedics

Waxman and Williams 2006 (24)
Survey of recent Australian Chinese medicine degree graduates investigating perceptions of confidence in various aspects of clinical practice. Contentvalidated survey with qualitative outcomes.

\section{Anonymous} questionnaire of the first cohort of occupational therapist graduates from Deakin University, Geelong.

Survey of Monash University (Melbourne) pre-employment students
The majority of final-year CM students perceived themselves to be somewhat adequately or adequately prepared to enter the workforce. Responses indicated a range of opinions on the strengths of educational courses and suggestions on how transition to clinical practice could be facilitated. These included the facilitation and development of: mentoring and other external clinic experiences; business establishment and management skills; support networks for graduates; and changes to the course structure/internship.

Results indicated recent graduates would like more clinical experience, support in developing their business and interpersonal skills, and the option of participating in a formal transition arrangement, such as mentoring, as organised by education providers and/or professional associations.

A significant positive relationship was found between respondents' perception of their curriculum and fieldwork experiences and their preparation for practice.

Two- thirds of final year students felt ill prepared for the employment application and selection process. Students were concerned that their education would not be recognised, a lack of workload, geographic isolation once employed, and the perception of being too young. 


\section{Paramedics}

Dawson 2008

(15)

Paramedics

McCall, Wray

\& Lord, 2009

(55)
Paramedic bachelor degree students and supervisors at Victoria University (Melbourne): interviews
Student perception of factors that affect their education in the clinical environment. Focus group discussions with undergraduate Bachelor of Emergency Health (Paramedic) students at Monash University.

\begin{tabular}{|c|c|c|}
\hline Paramedics & $\begin{array}{l}\text { O'Meara, } \\
\text { Tourle, } \\
\text { Madigan, and } \\
\text { Lighton, } 2011 \\
(56)\end{array}$ & $\begin{array}{l}\text { Longitudinal study } \\
\text { design using surveys } \\
\text { and a focus group, } \\
\text { investigating career } \\
\text { intentions and } \\
\text { identifying key factors } \\
\text { that influence career } \\
\text { choices. Conducted at a } \\
\text { Charles Sturt University } \\
\text { with paramedic and } \\
\text { nursing/paramedic } \\
\text { undergraduates. }\end{array}$ \\
\hline Paramedics & $\begin{array}{l}\text { O'Brien, } \\
\text { Hartley, } \\
\text { Dawson \& } \\
\text { Moore, } 2013 \\
\text { (52) }\end{array}$ & $\begin{array}{l}\text { Survey of final year } \\
\text { paramedic students at } \\
\text { Victoria University, } \\
\text { Australia. Written survey } \\
\text { with eight content- } \\
\text { validated dimensions } \\
\text { related to paramedic } \\
\text { practice and open- } \\
\text { ended questions that } \\
\text { elucidated qualitative } \\
\text { data. }\end{array}$ \\
\hline
\end{tabular}

Paramedic program provided a good theoretical background but students felt under-prepared in terms of practical experience working with ambulance services. Need for hospital placements identified (to provide experience with hospital environment).

Interviews of student supervisors suggest that practical skills of students in the course improve over time after employment and are the same as students trained in the post-employment model (in-house training).

Communication, appropriate placements, capacity building and adequate preparation for students emerged as major themes. It was concluded that communication, early identification of issues, and on-going quality evaluation is needed between the University, ambulance services, and students, in order to improve the quality of clinical education.

A number of factors were found to influence student career intentions, including personal situation, professional reasons, organisational factors and community expectations. Student needs to be addressed by Universities and paramedic employers include recognition of graduate attributes, attractive working conditions, further education opportunities, and the promotion of the paramedic as a health professional.

Clinical practice and placement experiences in the field emerged as key positive aspects of the students' higher education experience, as well as the perception that more and varied clinical placements in the course may better prepare the students for entry into the workforce. 